\title{
Violence, Peacebuilding, and Elite Bargains in Mozambique Since Independence
}

\author{
Alex Vines
}

\section{INTRODUCTION}

Mozambique was considered a successful case of peacebuilding after the end of the devastating post-independence civil war that ended in 1992. But the return to targeted armed conflict in 2013 between the government and RENAMO and the need for a new peace process has challenged that assumption. ${ }^{1}$ A new "definitive" peace agreement was finally signed between the government and RENAMO on August 6, 2019, but many Mozambicans question whether it will stick; and there is domestic and international anxiety over a growing violent crisis in northern Mozambique (Cabo Delgado Province, especially). Since late 2017, Mozambique has faced attacks by a violent Islamist extremist group that is active along its far northern coast. The group-known as Al Sunnah wa Jama'ah (ASWJ), among other names-has killed hundreds, often via beheading (Map 18.1). ${ }^{2}$

\footnotetext{
A. Vines $(\bowtie)$

Chatham House, London, UK

e-mail: avines@chathamhouse.org

(C) The Author(s) 2021

T. McNamee and M. Muyangwa (eds.),

The State of Peacebuilding in Africa, https://doi.org/10.1007/978-3-030-46636-7_18
} 


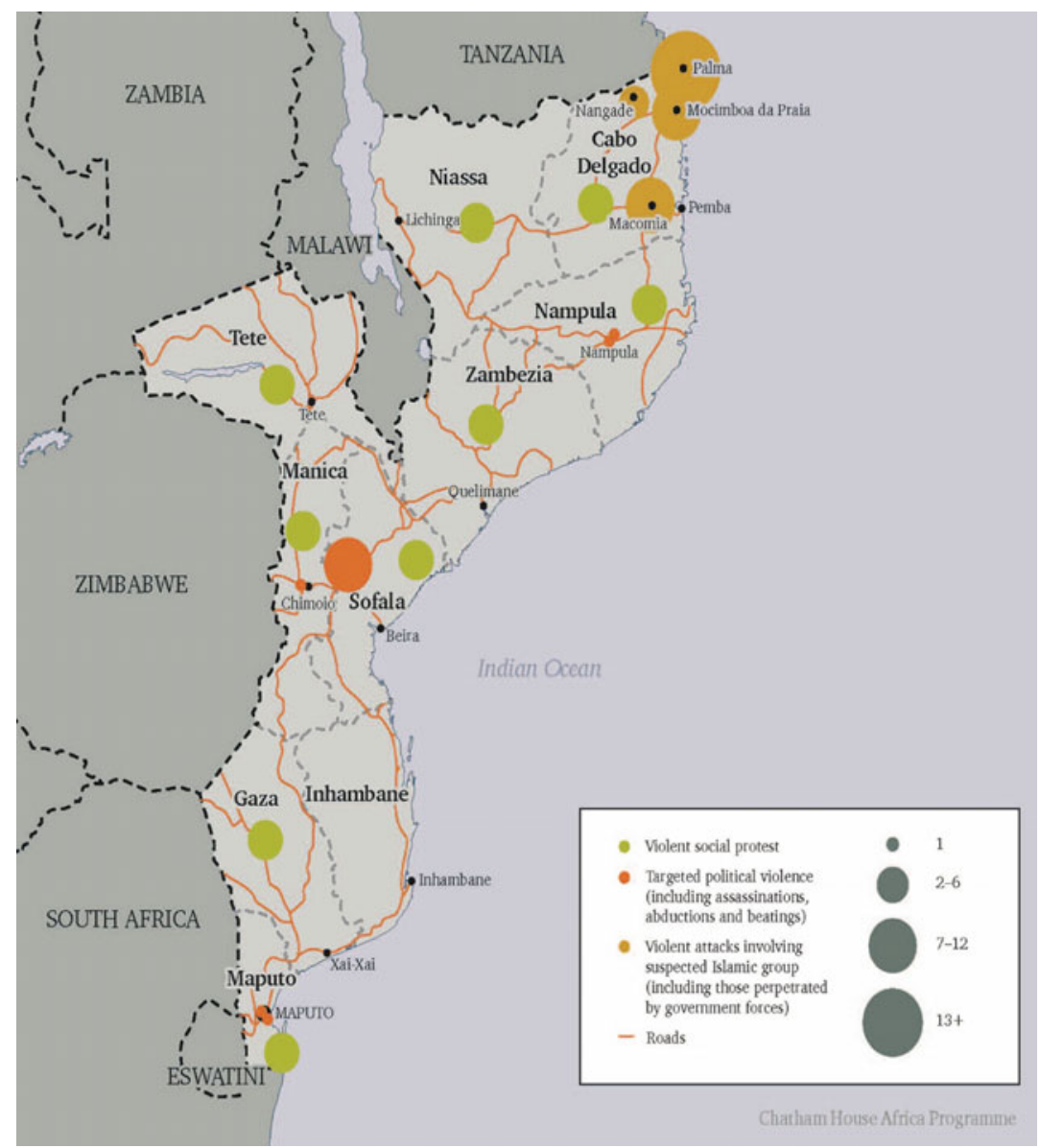

Map 18.1 Violence and social protest, 2017-2019 (Source Chatham House Africa Programme, adapted from AIM, ACLED, and author interviews)

These new and resumed old conflicts are occurring at a time of significant population growth, deepening inequality, and growing frustration at mainstream politics in Mozambique. The optimism of much of the 2000s that followed the end of the civil war has evaporated; Mozambique remains one of the world's least developed countries, ranking 180th out 
of 189 countries. ${ }^{3}$ Up to 2019 , its state finances have relied upon significant international loans, and until recently, development aid represented half of the state budget. ${ }^{4}$

Mozambique sustained rapid post-civil war growth with an annual average of 8.4 percent GDP growth until 2015. In 2016, however, growth fell to 3.8 percent from 6.6 percent in 2015, and in 2018 slumped further, to 3.3 percent. The International Monetary Fund (IMF) has attributed this decline to weak global commodity prices, poor weather conditions, and "the issue of undisclosed loans in the spring of 2016 and the ensuing freeze in donor support." 5 The RENAMO-government conflict also may have contributed to the slow-down and the effects of the two cyclones in 2019 have further reduced growth in the short to medium term.

The discovery of world-class gas reserves has generated renewed optimism about the country's future. Natural gas production will drive large gains in economic growth from the mid-2020s to the early 2030s; but, rapid population growth, rising inequality, and the lack of access to basic services and infrastructure means that much of this growth may not benefit the poor (Map 18.2). ${ }^{6}$
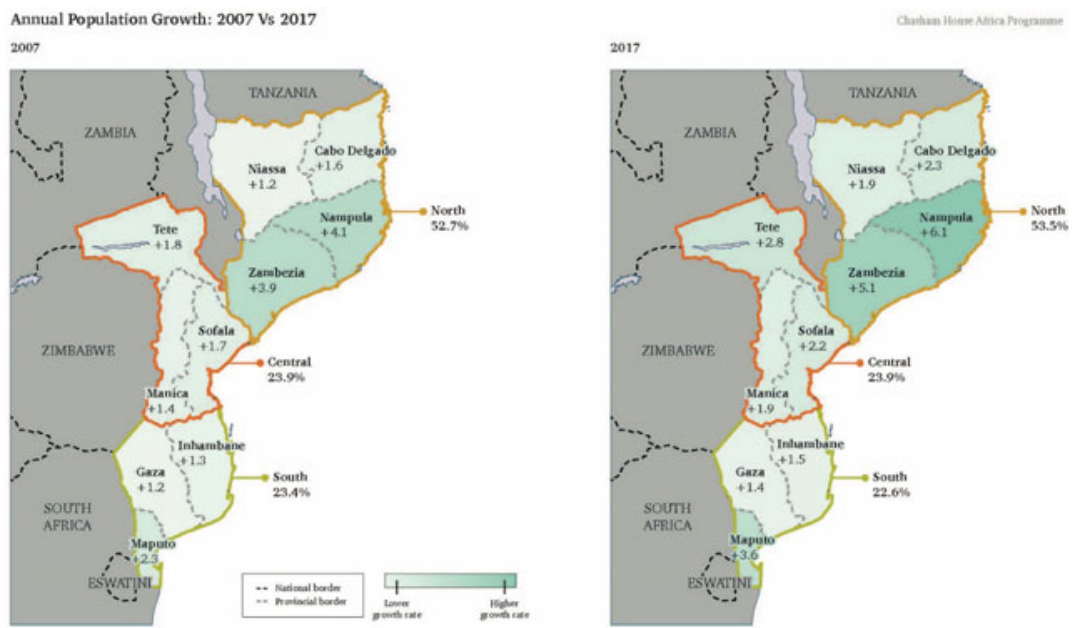

Map 18.2 Population growth (Source Chatham House Africa Programme) 
Most Mozambicans, an estimated 86 percent or more of the workforce, make their living in the informal sector, often as subsistence and cash crop farmers, fishermen, and small-scale manufacturers and traders. Productivity within this large segment of the economy, however, is constrained by little access to credit, business training, or technical expertise. Youth unemployment is a particular challenge. Nearly 68 percent of Mozambicans are age 25 or younger, and many young people from rural areas, home to 65 percent of the population in 2017, often gravitate toward cities, where job growth has not kept up with increasing education and training rates-even though these are low. ${ }^{7}$

It is in this context that domestic and international peacebuilding efforts have occurred. There has never been one plan, but a collection of initiatives, at times incorporated into national strategies, at other times technical interventions to address a particular sector or priority. ${ }^{8}$ This chapter examines the many domestic and international efforts to support peacebuilding efforts in Mozambique since 1975. It highlights that conflict and contestation did not start or end with the civil war but is an ongoing process, and that parts of Mozambique remained unstable despite the Rome General Peace Accord (GPA) of 1992 because state-centric approaches to peacebuilding largely failed. ${ }^{9}$

\section{HistoricAl BACKGROUND}

Mozambique's history is deeply tied to complex regional politics (compounded by divisions between the center and the peripheries of the country) and failures in nation-building. For much of the colonial period up to 1942 , Mozambique was divided into separate administrative zones, which fragmented the colony and prevented the emergence of a common system of law and administration. The location of the capital in the extreme south of the country, and the proximity of South Africa, concentrated resources and the modern sector of the economy in that region, while much of the rest of the country continued to be relatively marginalized. ${ }^{10}$ The 1977-1992 civil war also helped to accentuate regional differences, with RENAMO's activities concentrated in the center of the country. The discovery of world-class gas reserves in northern Mozambique may further accentuate these regional differences.

Mozambique obtained independence in June 1975, following a nationalist struggle against Portuguese colonialism by FRELIMO. ${ }^{11}$ In February 1977, FRELIMO formally declared its transformation from the 
liberation movement into a Marxist-Leninist vanguard party. The decision came at a time when there were growing numbers of skirmishes between Mozambique and Rhodesia, and when the party was seeking to attract military aid from Eastern Europe and the Soviet Union. ${ }^{12}$

Following FRELIMO's rise to power, "purification" and persecution of those who had collaborated with the colonial regime led many Mozambicans to leave the country, some of whom joined RENAMO. FRELIMO increasingly found that it could not defeat RENAMO, partly as a result of its guerrilla tactics and partly because of the centralization of the state, which meant that many regions had never benefitted from a centralized government in Maputo and their politics and loyalties were regional and local as a result.

FRELIMO ended the one-party system in 1990. Yet, the party has continued as the dominant force in state and society, winning all six presidential and parliamentary elections. ${ }^{13}$ Mozambique is not formally a one-party state, but the ruling party is still so deeply entrenched in the state apparatus that in practice it is still hard to separate one from the other. Similar to other "liberation movement states" in southern Africa, the party has blurred the interests of the movement, the state, and personal interests of key individuals. FRELIMO has always sought to keep a tight grip on political power. ${ }^{14}$

\section{The Post-independence Civil War}

In 1976, Mozambique imposed sanctions against neighboring Rhodesia's white minority regime, which disrupted the Mozambican economy and deprived its ports of lucrative earnings. It also marked the start of hostile relations between the two countries: in 1977, the Rhodesian Central Intelligence Office (CIO) began to arm and train the nascent RENAMO opposition force-which at that point was called the MNR - in retaliation for Mozambique's support for Zimbabwe nationalist guerrillas. ${ }^{15}$ This conflict can be broken down into different episodes ${ }^{16}$ : the Rhodesian phase (1977-1980); the overt South African phase (1980-1984) ${ }^{17}$; the covert South African phase (1984-1988); and the post-South African phase until 1992. 


\section{Failed Attempts to End the War}

The transfer of RENAMO to South Africa marked a turning point in the war, which soon began to escalate. The South African government used RENAMO as a tool for destabilizing Mozambique and as a counter to Mozambique's support for the African National Congress (ANC). ${ }^{18}$ FRELIMO made a bid to end the war in 1984 when it signed the Nkomati non-aggression pact with Apartheid South Africa, followed by proximity talks in 1985 with RENAMO, but both failed due to South African duplicity. Indeed, RENAMO changed its military strategy as South Africa significantly reduced its covert aid to the rebels. ${ }^{19}$ In 1986, Mozambique's first president, Samora Machel, was killed in a mysterious plane crash and Joaquim Chissano, Mozambique's foreign minister since independence, became president. This change in leadership led to a series of reforms and, ultimately, official peace negotiations with RENAMO that began in $1990 .^{20}$

While the roots of the peace process began in 1982, South Africa's covert policy of support for RENAMO had eroded earlier attempts to seek a negotiated settlement. The Mozambican government was also not prepared to offer significant positions of patronage in government as a guarantee of RENAMO's survival. Only in the late 1980s, with declining external support for RENAMO and greater pressures on the government from the vacuum left by the end of the Cold War and the collapsing Eastern Bloc, were serious peace talks possible.

In this new climate, Community Sant' Egidio, a liberal Catholic movement, was well placed to play a constructive role in the peace process. It was able to persuade RENAMO to engage in dialogue as a result of the contacts its members had in Mozambique and its understanding of the dynamics of the conflict, and helped the rebels transform vague requests into communicable proposals. However, once the 1lth round of peace talks got underway in June 1992, Community Sant' Egidio's role was reduced. Discussions on military issues brought the United States, France, Britain, and Portugal into the negotiations as observers, and the momentum grew for twin-track diplomacy and the urgent need to "Summitize" and "Africanize" the process. 


\section{The Rome General Peace Accord}

After 12, often torturous, rounds of negotiations, the General Peace Accord (GPA) was eventually signed in Rome on October 4, 1992 between President Joaquim Chissano and RENAMO leader, Afonso Dhlakama. The implementation of most of the key provisions of the GPA was placed in the hands of the United Nations (UN). According to UN Security Council Resolution 797, the newly established United Nations Operation in Mozambique (ONUMOZ) was to perform a series of tasks such as monitoring and verifying the implementation of the ceasefire, including the retreat of Malawian and Zimbabwean units from Beira, Limpopo, and Nacala transport corridors, and protecting these corridors with its own forces.

In order to fulfill its mandate, ONUMOZ was provided with both civilian and military departments. It was mandated to monitor the cantonment, disarmament, and demobilization of nearly 110,000 combatants from both sides, as well as the creation of the new army and the resettlement of between five and six million refugees and displaced people. The cost was estimated at US \$331 million (one million dollars per day) until November 31, 1993. ${ }^{21}$

By 1996, 87 percent of demobilized soldiers had been integrated into society, and most had secured a food supply or small guaranteed income. The total reintegration budget was US $\$ 94.4$ million, of which US \$35.5 million was allocated to support two years of cash for registered ex-combatants and US $\$ 33.7$ million went directly to demobilized soldiers. In all, some 92,000 soldiers benefitted, about 71,000 from the government forces and 21,000 from RENAMO.

One of the surprises of the 2013 resumption of conflict between RENAMO and the government was the availability of arms for RENAMO. According to the Mozambican Force for Crime Investigation and Social Reinsertion (FOMICRES), between three and four million weapons were circulating at the end of the war in $1992 .{ }^{22}$ During the 1992-1994 peace process, the priority of ONUMOZ was to help RENAMO transform itself into a political party and contest national elections. The UN priority was to dismantle RENAMO's command and control structures, and also disperse ex-combatants through the pay-andscatter program. Disarmament was not a priority, and the UN's Special Representative, Aldo Ajello, admitted that he considered that muscular disarmament would undermine the peace process. ${ }^{23}$ 
The Rome GPA delivered over 20 years of peace. It was followed by an aid bonanza that rapidly transformed the FRELIMO elite into a patrimonial political class that became increasingly determined to hang on to power at all costs. Gas and coal reserves heightened the stakes further, dividing the FRELIMO elite over who had access to the spoils and triggering RENAMO's decision to return to targeted armed violence in 2013, to push for a new elite bargain with FRELIMO in order to also benefit from future coal and gas rents. Sumich and Honwana flagged the fragility of this GPA elite bargain in their assessment of FRELIMO and its disinclination to seriously share power. They concluded that:

[S]ince independence power has primarily been located in the Frelimo party, not in supposedly neutral state structures that could be inherited in a reasonably intact manner by another political force. Thus the very success of the party in rebuilding their hegemony and their disinclination to share power with social forces outside of their control could intensify the divisions and inequalities that helped to fuel the civil war in the first place. $^{24}$

As mentioned above, until 2013, Mozambique was regarded as having passed through a successful post-conflict transition. In April 2013, there was a return to limited armed conflict between fighters of the former rebel group (RENAMO) and Mozambican government forces. ${ }^{25}$ A new agreement in September 2014 ended regular armed skirmishing in central Mozambique, but armed violence once more resumed in 2015 and persisted until late December 2016, focused primarily on commercial links and public services. Fresh negotiations for a new political deal finally reached a new accord in August 2019.

RENAMO never expected to capture the Mozambican state, but has always sought a military or political stalemate through which it can extract elite bargains from the dominant party, FRELIMO, resulting in a temporary political settlement. ${ }^{26}$

\section{Learning from the PASt for Future Peacebuilding}

One of the conclusions that can be drawn from RENAMO's strategy since 2013 is that maintaining armed men who are prepared to challenge the government enhanced RENAMO's political standing in the short term, and has resulted in a new process to reach a new elite bargain 
in the longer term. In addition, two other lessons can be drawn from the resumed violence of 2013-2014 and subsequent clashes. First, disarmament, demobilization, and reintegration (DDR) efforts were seen as a finite, short-term technical process that did not cover political inclusion. This meant that after a decade of peace, international donors concluded that Mozambique had undergone a successful post-conflict transition and that support for the efforts of non-governmental organizations (NGOs) in this field was no longer a priority.

Second, disarmament should not have been neglected, and ONUMOZ missed an opportunity in this regard. After its withdrawal, the opportunity to disarm diminished and only a small percentage of weapons were given up through official and NGO efforts. RENAMO has maintained armed men and weapons stockpiles over 20 years, and there was early warning of this. In 2012, the NGO FOMICRES, ${ }^{27}$ for instance, located large arms caches in five districts in Sofala province, including heavy weapons, but politically it was not able to access them for destruction. ${ }^{28}$ While recognizing that RENAMO would never have handed over all its weapons to ONUMOZ, more effort during its mandate would have reduced stockpiles further, especially if international partners had continued to support disarmament and support alternative livelihoods of ex-combatants in central Mozambique.

RENAMO's continued access to an armed militia is also the result of a provision in the Rome GPA, which stipulated that the former rebels could maintain bodyguards (who would enjoy police status) as a "transitional guarantee" until elections in 1994. The objective then was for the police to take over these responsibilities, but that Dhlakama's "bodyguards" could, if a list be provided, receive police training. Although a list was eventually provided, the government insisted that once trained, these men must obey police orders. In January 1998, worried about losing authority over these men, Dhlakama categorically refused to allow his bodyguards to be incorporated into the police. It seems that a mixture of fear of losing his prime asset (armed men) and concern over his own security drove this decision.

The result was that from 1994 to 2013 the Mozambican government reluctantly accepted the de facto presence of several hundred armed RENAMO personnel resident in the Maringué and Cheringoma districts of Sofala province, who occasionally paraded with weapons and intimidated local FRELIMO activists. ${ }^{29}$ A small group of them also escorted 
Dhlakama and provided security for his house in Nampula as his "presidential guard." They were poorly uniformed, with shoes falling off and brandishing old weapons. ${ }^{30}$ The government wanted to disarm this "presidential guard" completely, and offered to integrate it with the national police force, but this offer was rejected. A further opening to reintegrate members of this RENAMO militia emerged from the September 2014 agreement that temporarily halted hostilities, but depended on their fitness and the provision of a new list. That list was never forthcoming but finally, in July 2019, a RENAMO list of 5,211 fighters, who were not integrated after the GPA, was provided.

\section{RENAMO's Electoral Fortunes}

RENAMO has contested all six presidential and parliamentary elections since the war ended in 1992. The October 1994 elections enjoyed a high voter turnout of above 85 percent and there was little violence in the lowkey campaign, although there was some intimidation by both sides in their stronghold areas. The results of all six elections up to 2014 show a generally clear and consistent pattern: FRELIMO has commanded a majority overall and dominated in the capital, the south, and the extreme north, while RENAMO remained strong among voters in the center and north. However, RENAMO was visibly weakened after the 2009 elections, and that parliament was dominated by FRELIMO, which won 75 percent of the votes and had majorities in all former RENAMO strongholds. Positions in the National Assembly were allocated to parties in proportion to their number of parliamentary seats (Fig. 18.1).

After 1994, and especially after the 1999 national election results, FRELIMO concluded that RENAMO posed an electoral risk. ${ }^{31}$ In response, FRELIMO aggressively countered RENAMO, at times this involved intimidation and harassment of its supporters, especially during electoral cycles. As a result, there have been electoral irregularities in all the subsequent elections. In the October 2019 elections, there were widespread reports of irregularities. Experts suggest RENAMO may have lost five seats as a result but did not win outright, as they claimed.

\section{The 2019 Peace Accords}

The Rome agreement lasted until 2013 when RENAMO returned to targeted armed conflict, ambushing cars, buses, and trains, and attacking 


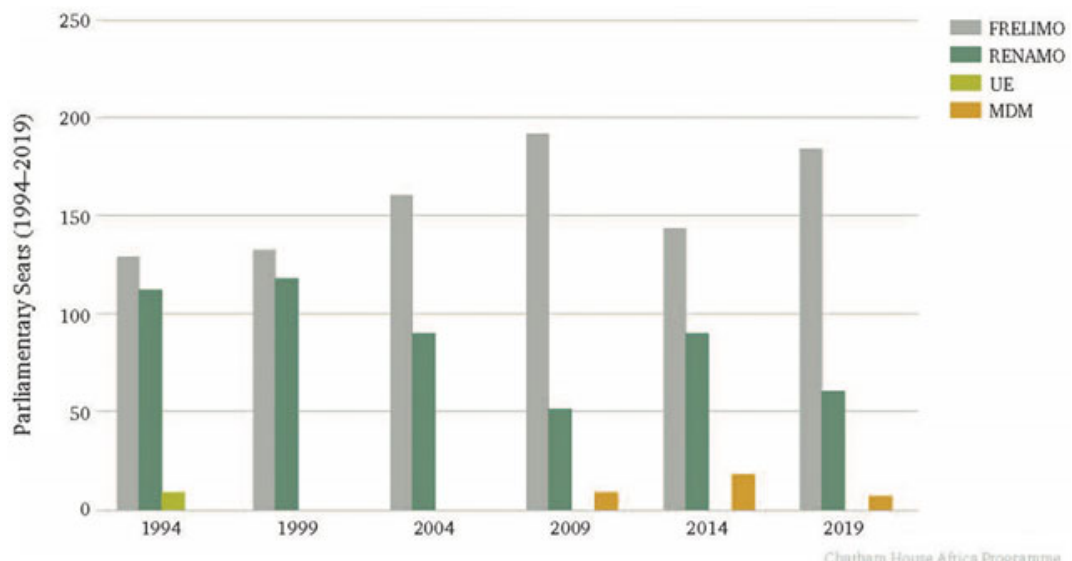

Fig. 18.1 Parliamentary elections (Source Chatham House Africa Programme, adapted from República de Mocambique Comissão Nacional de Eleicoes [CNE] and Secretariado Tecnico da Administração Eleitoral [STAE], http://www.stae. org.mz/)

government facilities. The violence was concentrated in the central Mozambican provinces of Manica and Sofala. Including government counter-measures, this resumed conflict in its two phases between 2013 and 2016 resulted in at least 150 killed and 500 injured (Map 18.3). ${ }^{32}$

So why did RENAMO return to armed conflict in 2013 after 20 years of peace and many years of peacebuilding efforts? And what can be done to avoid a resumption of hostilities going forward? FRELIMO's strategy toward RENAMO was the prime culprit. RENAMO gave FRELIMO an existential fright during the 1999 national elections, when RENAMO's former leader, the late Afonso Dhlakama, nearly won the presidency with 47.7 percent of the vote (some believe he actually did win-see Fig. 18.1). This convinced Armando Guebuza to seek total dominance when he became president in 2004, in an effort to guarantee FRELIMO control. This backfired, instead convincing Dhlakama that he needed to return to armed conflict to extract new concessions.

Reaching a new peace accord took six years, with three different peacebuilding efforts, first by faith leaders, then multiple international mediators, and finally an elite process driven initially by President Nyusi and Dhlakama (who died in 2018 and was succeeded by Ossufu Momade) 


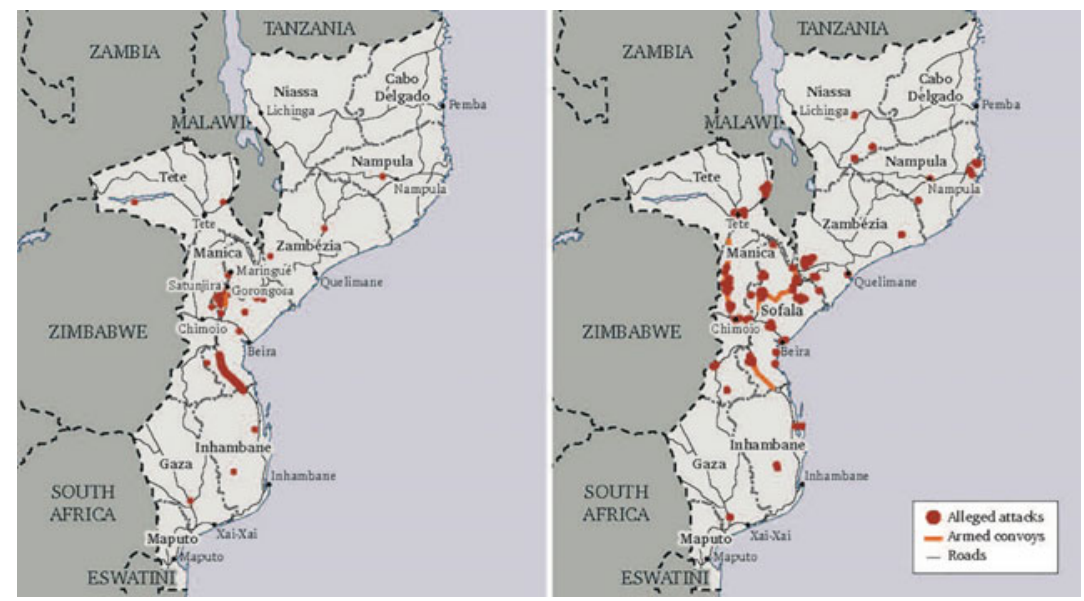

Map 18.3 RENAMO armed clashes 2013-2014 (left) and 2015-2016 (right) (Source Chatham House Africa Programme, adapted from @Verdade, AIM, ACLED, and author interviews)

supported by the Swiss Ambassador to Mozambique, Mirko Manzoni, and mediators Neha Sanghrajka and Jonathan Powell. ${ }^{33}$

The peace agreements of August 1 and 6, 2019 built on these past peace processes. They were signed in Gorongosa and Maputo by President Filipe Nyusi and RENAMO leader, Momade. They were the third such agreement between the two parties, designed to bring an end to 42 years of violent competition between FRELIMO and RENAMO, somewhat weakened due to Dhlakama's death, which caused some fragmentation with RENAMO.

The August 6 Maputo Accord was witnessed by the chair of the African Union and four presidents, including South Africa's Cyril Ramaphosa, as well as several past mediators. President Nyusi reminded the large crowd in Maputo that the road to peace has had past setbacks. ${ }^{34}$

This new elite bargain was also based on the assumption that there would be increased decentralization with the opportunity for RENAMO to win governorships in ten Mozambican provinces in exchange for meaningful DDR for RENAMO's armed militia. (The process for the 5,221 earmarked RENAMO fighters started in central Mozambique at the end 
of July 2019.) Nobody, including FRELIMO strategists, imagined that RENAMO would fail to win majorities in one or two provinces.

This deal had been ripe for agreement, but the death of Dhlakama resulted in a power struggle within RENAMO and delayed the process. Gradually Momade asserted some authority, resulting in an attempt to pivot the party away from central Mozambique toward Zambézia and Nampula provinces. However, the October 2019 election results failed as RENAMO's electoral campaign was artisanal compared to an industrial FRELIMO effort.

There had already been splintering in RENAMO when, beginning in July 2018, a self-styled RENAMO military junta challenged Momade's authority and elected its own leader, Lieutenant General Mariano Ngongo. This group was small (up to 200 people) but enjoyed some support in central Mozambique. Armed attacks in central Mozambique during the second half of 2019 were a reminder that a few armed men can effect serious political and social disruption (Map 18.4).

RENAMO's armed supporters seek a lasting accommodation; FRELIMO's elite also want political stability to attract international investment. The benefits of the elite bargain for RENAMO were to have included elected governorships, payment for disarmament and employment, and development opportunities. However, RENAMO's poor elections results in October 2019 complicated this calculation.

\section{Importance of Decentralization for Peacebuilding}

Meaningful decentralization by the government and full demobilization by RENAMO had been the key issues of negotiations in 2018 and 2019 . In early 2018, President Nyusi and Dhlakama negotiated a framework accord on political decentralization. Following Dhlakama's death, there were fears this might not last. But in May 2018, parliament enacted a series of constitutional amendments to prepare for deepened decentralization. These provided for elected provincial, district, and municipal assemblies (with the leading delegate in the party with a simple majority, heading them). Following the work of the commission on decentralization, a constitutional amendment on the issue was passed in the National Assembly in May 2019. The following month, the president promulgated the Law of Punctual Review of the Constitution of the Republic of Mozambique. ${ }^{35}$ 


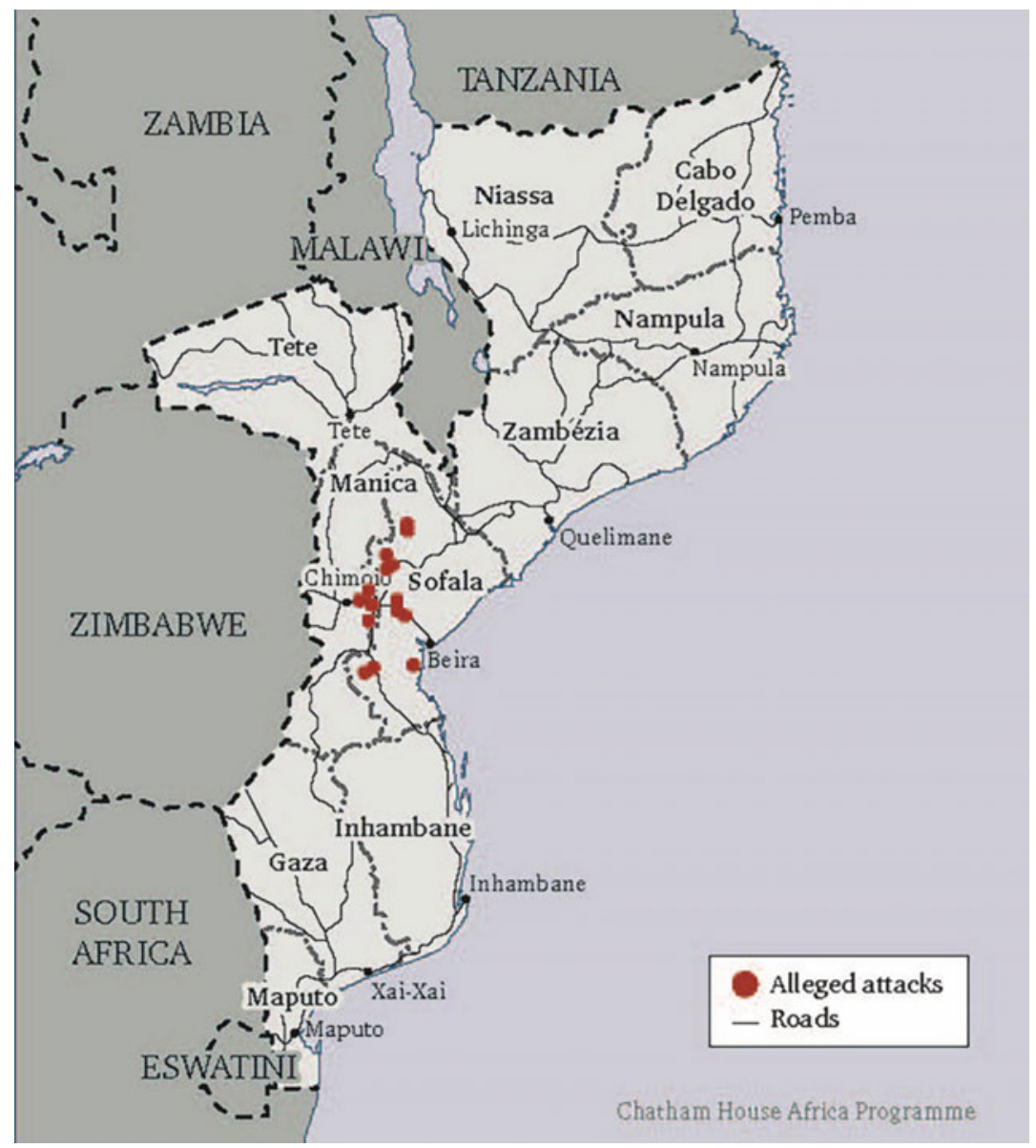

Map 18.4 Armed Attacks, August-December 2019 (Source Chatham House Africa Programme, adapted from @Verdade, AIM, ACLED, and author interviews)

At the time of writing in January 2020, RENAMO's comprehensive disarmament remains the key government demand. Concessions for reintegrating RENAMO combatants into the armed forces (FADM) and police could be a sticking point. In this regard, the Memorandum of Understanding (MOU) on Military Affairs includes security provisions 
for the placement of RENAMO ex-combatants into senior positions in the army and police force. New, symbolic senior posts are being created to absorb some of these former fighters and RENAMO has raised the idea of creating a "provincial police force."

International partners will need to learn from past mistakes. They need to commit to long-term guarantees to DDR efforts in hotspots, particularly parts of central Mozambique and Tete province, and focus on bringing Momade - and the RENAMO military splinter group led by Lt Gen. Mariano Ngongo-into a process that incentivizes non-violent politics. A basket fund has been established to channel financing for DDR activities and a DDR camp has been constructed in central Mozambique by a group of military experts. Too much focus on austerity by international donors and the international financial institutions at this critical moment might backfire. Their engagement, instead, needs to be conflict-sensitive and not time-dependent. Like many other guerrilla groups, RENAMO will only gradually disarm its gunmen and is likely to keep hidden arms caches as an insurance policy. As a response, the best strategy is to build up political confidence and economic opportunity so that gradually this armed wing becomes redundant.

International partners will also need to review their past peacebuilding efforts to encourage local-level political pluralism. As Roberta Machietto observed:

[I]t is clear that economic and political liberalization...have not translated into a fair redistribution of the peace dividend. On the contrary, liberalization measures have been "adapted" in such a way as to consolidate the regime of the dominant party, only now with the legitimization of the international community. ${ }^{36}$

Machietto examined an ongoing national micro-credit program by the government called the District Development Fund (the "7 Million") designed to support decentralization and aimed at reducing poverty and inequality in Mozambique. Her examination of the 7 Million was based upon field research in Nampula province and showed that, despite its limitations, some money and decision-making was devolved to local districts. This gave some communities experience of the possibilities of increased accountability by their local officials through the Local Councils and associated Local Development Committees. Unsurprisingly, FRELIMO party loyalty was an advantage for access to micro-credit from this 
program. ${ }^{37}$ However, as FRELIMO found in the 2018 local elections, this is no longer enough to win votes in Nampula province. FRELIMO will increasingly have to work harder to retain patronage.

Another major challenge to sustainable peacebuilding is the growth of corruption and the elite use of political influence to accumulate private wealth. ${ }^{38}$ This trend accelerated over the post-civil war period with worrisome implications for the economy and stability. The post-2015 economic decline followed disclosures that the government had failed to report to the IMF US $\$ 2.2$ billion in state-guaranteed debt, which violated the terms of Mozambique's cooperation with the IMF. ${ }^{39}$ Two foreign banks provided these loans, in an allegedly corrupt manner, to state-owned firms registered as private entities and controlled by state intelligence officials. These secret loans, most of them acquired in 2013, added around 30 percent to the country's foreign debt. ${ }^{40}$ This scandal transformed the political and economic landscape and led to widespread anger at FRELIMO. The roots of this probably lie in the shock of the 1999 election results, when FRELIMO concluded that it needed regular funds for patronage and to ensure it won future elections. One response was to create a financial and business arm for the party, SPI-Gestão e Investimentos SARL (SPI). ${ }^{41}$

The fall-out from the undisclosed loan scandal is ongoing and more revelations will emerge on what exactly happened in 2013. Elite corruption was clearly part of the logic. But President Guebuza was already wealthy. It is probable that, as he neared the end of his second and last term in his presidency, he considered how to secure a further term as party leader and also to ensure he remained the de facto power behind whoever succeeded him in the presidency. ${ }^{42}$ Conflict with RENAMO in 2013 suited these ambitions but by 2014 , as his influence declined inside FRELIMO, and RENAMO's armed actions damaged the Mozambican economy, he sought a new settlement with the former rebels. A potent reminder: peacebuilding in Mozambique is multi-layered, open-ended, progresses in fits-and-starts, and is prone to setbacks.

\section{CONCLUSION}

The FRELIMO landslide victory following the sixth national multi-party elections in October 2019 has complicated the elite bargaining and peacebuilding efforts. Since Mozambique's first-ever multi-party elections in 1994, FRELIMO has pursued a strategy of co-option and division of 
RENAMO through elite bargains. FRELIMO's post-conflict strategy was initially, under Chissano, to weaken RENAMO's support base in central Mozambique through compromise and patronage, and then, under Guebuza, obtain total FRELIMO domination across Mozambique. Guebuza's strategy spectacularly backfired, humiliating Dhlakama and radicalizing RENAMO's ex-combatants, resulting in their push for resumed targeted armed violence. This violence was rewarded in the 2014 elections, especially by voters in central Mozambique, strengthened Dhlakama's leadership position in RENAMO, and again postponed long-needed party reform. ${ }^{43}$

But, by 2015 Dhlakama also miscalculated, believing his threat of further violence would win more concessions. Instead, his threats increased splits in FRELIMO over its RENAMO strategy and weakened President Nyusi's attempts to reach a lasting accommodation. The result was at least one assassination attempt on Dhlakama and increased violence by both sides, despite a haphazard "good offices" effort by various international mediators. Common frustration of this process encouraged President Nyusi and Afonso Dhlakama to cut intermediaries and start bilateral talks. Helped with logistics and focus by a new Contact Group, led by Swiss Ambassador Manzoni, this process has made tentative progress. Encouragingly, conflict has not resumed and a new binding agreement was signed by both sides in August 2019.

Some 27 years after the Mozambican conflict ended, many RENAMO combatants have successfully reintegrated, but a hardened core of exmilitia remain, mainly in central Mozambique. Overall, Mozambique has remained an example of mostly successful demobilization, but poor peacebuilding success toward elite reintegration. Mozambican domestic politics is partly to blame for this, but so too is past international complacency. Mozambique's peace was not secure, as many blithely assumed.

The situation today in Mozambique also highlights the degree to which these bargaining processes are long-term and there is still a need to look at strategies to accommodate clusters of combatants that remain cohesive, particularly in central Mozambique. The August 2019 accord is backed up by development commitments for central Mozambique and promises of a better retirement for RENAMO's gunmen.

A durable peace settlement requires compromise by FRELIMO and an acceptance that RENAMO and other political parties can capitalize on some of the government's shortcomings. Going forward, the danger is that RENAMO's military wing will continue to fracture; there is also 
uncertainty over Momade's commitment to historical loyalties from the 1977-1992 war, and how being weakened by his poor election results will impact events.

The poor electoral showing by RENAMO is a new test-having failed to win even a governorship. The elite bargain was for indirectly elected governorships for RENAMO, payment for disarmament, and employment and development opportunities. Without governorships, can this deal stick? Armed attacks in central Mozambique illustrate the fragility of the deal and the need to tackle the RENAMO splinter group present in the region. If the insecurity and violence there can be addressed, the domestic and international focus should move onto longer-term peacebuilding focus, such as poverty reduction, combating inequality, education, and solving the escalating security crisis with Islamic militants in Cabo Delgado province.

\section{Key RECOMMENDATIONS}

1. International partners need to shift their approach to align with new political and conflict dynamics. More long-term, targeted disarmament, demobilization, and reintegration in potential flash points in central Mozambique is required. On the economic side, donors need to be mindful that austerity measures, if pushed too hard, could backfire and re-militarize competition for scarce resources.

2. Decentralization and local level political pluralism should be at the beart of future peacebuilding. There remains an acute lack of trust between Mozambique's main political formations. Building political confidence and economic opportunities for all is the best way to finally make the armed wing of RENAMO redundant.

\section{Notes}

1. Cyprian Muchemwa and Geoffrey Harris, "Mozambique's Post-War Success Story: Is It Time to Revisit the Narrative?," Democracy and Security 15, no. 1 (2018): 25-48; and Andrew Brooks, "Was Africa Rising? Narratives of Development Success and Failure Among the Mozambican Middle Class," Territory, Politics, Governance 6, no. 4 (2018): 447-467.

2. Simone Haysom, "Where Crime Compounds Conflict: Understanding Northern Mozambique's Vulnerabilities," Global Initiative Against 
Transnational Organized Crime (October 2018), https://globalinitia tive.net/northern_mozambique_violence/; Gregory Pirio, Robert Pittelli, and Yussuf Adam, "The Emergence of Violent Extremism in Northern Mozambique," Africa Center for Strategic Studies, March 25, 2018, https://africacenter.org/spotlight/the-emergence-of-violentextremism-in-northern-mozambique/.

3. UNDP, Latest Human Development Index (HDI) Ranking, Statistical Update 2018, http://hdr.undp.org/en/2018-update. The number of people living in extreme poverty has risen by over 5 million since 1995, the number of those without access to improved water has risen by nearly 4 million and Mozambique still has one of the lowest levels of educational attainment in the world.

4. Aslak Orre and Helge Rønning, Mozambique: A Political Economy Analysis, NUPI/CMI, 2017, 18. https://www.cmi.no/publications/file/ 6366-mozambique-a-political-economy-analysis.pdf.

5. IMF, "IMF Executive Board Concludes 2017 Article IV Consultation with Republic of Mozambique," March 7, 2018; and GDP data from IMF, World Economic Outlook database, April 2019.

6 . The absolute number of people living in extreme poverty is forecast to be nearly the same in 2040 ( 18.7 million) as it is today ( 19 million).

7. Alex Porter et al., "Prospects and Challenges: Mozambique's Growth and Human Development Outlook to 2040" (ISS Report, June 28, 2017), https://issafrica.org/research/books-and-other-publications/prospectsand-challenges-mozambiques-growth-and-human-development-outlookto- 2040 .

8. Lisa Reppell, Jonathan Rozen, and Gustavo de Carvalho, "Planning for Peace: Lessons from Mozambique's Peacebuilding Process" (ISS Paper 291, June 2016), https://issafrica.s3.amazonaws.com/site/uploads/Pap er291.pdf.

9. The importance of local-level politics and neo-traditionalism and how they provide relevant insights for understanding peacebuilding and state formation in Mozambique today, See, Bjørn Enge Bertelsen, Violent Becomings: State Formation, Sociality, and Power in Mozambique (Berghahn Books, 2016).

10. Malyn Newitt, A Short History of Mozambique (London: Hurst, 2017), 22.

11. Newitt, A Short History of Mozambique.

12. John P. Cann, Counterinsurgency in Africa: The Portuguese War of War, 1961-1974 (Westport and London: Greenwood Press, 1997).

13. Bernhard Weimer and João Carrilho, Political Economy of Decentralisation in Mozambique: Dynamics, Outcomes, Challenges (Maputo: IESE, 2017), 49-52. 
14. Alex Vines, "Are Southern Africa's Liberation Movements in Crisis," Newsweek, August 16, 2016, https://www.newsweek.com/are-southernafricas-liberation-movements-crisis-490642.

15. Ken Flower, Serving Secretly: An Intelligence Chief on the Record, Rhodesia into Zimbabwe, 1964-1981 (London: John Murray, 1987).

16. Alex Vines, Renamo: From Terrorism to Democracy in Mozambique? (London: James Currey, 1996).

17. RENAMO maintained three overall provincial commands-divided into regions-all named after animals such as Crocodilo, Gato and Leão. See Michel Cahen, "The War as Seen by Renamo: Guerilla Politics and the 'Move to the North' at the Time of the Nkomati Accord (1983-1985)," in The War Within: New Perspectives on the Civil War in Mozambique 1976-1992, Eric Morrier-Genoud, Michel Cahen, and Domingo M. do Rosário (eds.) (London: James Currey, 2018), 109-143. He also suggests that the Nkomati Accord was a driver for RENAMO to develop a social base but "still in its early days in 1984 (143)" and concludes that RENAMO was a "plebian guerrilla movement" within late capitalism; See also, Stephen A. Emerson, The Battle for Mozambique: The Frelimo-Renamo Struggle, 1977-1992 (30 South Publishers, 2013).

18. Vines, Renamo: From Terrorism to Democracy in Mozambique, 22-25.

19. Ibid., 22-25.

20. Margaret Hall and Tom Young, Confronting Leviathan: Mozambique Since Independence (London: Hurst, 1997), 191-192.

21. Richard Synge, Mozambique: UN Peace-Keeping in Action, 1992-1994 (United States Institute of Peace, 1997).

22. Laini Reisman and Aly Lalá, Assessment of Crime and Violence in Mozambique \& Recommendations for Violence Prevention and Reduction, Open Society Foundations Crime and Violence Prevention Initiative \& Open Society Initiative for Southern Africa, March 2012.

23. Interview with Aldo Ajello, Rome, October 17, 2012. Others consider this as one of the flaws and that this was a lesson learned by the UN DPKO for future operations. Interview with Owen Greene, University of Bradford, Bradford, March 2, 2017.

24. Jason Sumich and João Honwana, "Strong Party, Weak State? Frelimo and State Survival Through the Mozambican Civil War: An Analytical Narrative on State-Making," Crisis States Research Centre, Working Papers Series No. 2 (2007): 22, http://www.lse.ac.uk/international-dev elopment/Assets/Documents/PDFs/csrc-working-papers-phase-two/ wp23.2-strong-party-weak-state.pdf.

25. Alex Vines, "Afonso Dhlakama and RENAMO's Return to Armed Conflict Since 2013: The Politics of Reintegration in Mozambique," in Warlord Democrats in Africa: Ex-military Leaders and Electoral Politics, Anders Themnér (ed.) (London: Zed Books, 2017). 
26. Carrie Manning, "Conflict Management and Elite Habituation in Postwar Democracy: The Case of Mozambique," Comparative Politics 35, no. 1 (2002): 63-84.

27. Gary Littlejohn, "Secret Stockpiles, Arms Caches and Disarmament Efforts in Mozambique," A Working Paper of the Small Arms Survey, September 21, 2015, http://www.smallarmssurvey.org/fileadmin/docs/ F-Working-papers/SAS-WP21-Secret-Stockpiles.pdf.

28. FOMICRES is led by ex-RENAMO and was able to access areas of central Mozambique other NGOs could not. Over the last decade, FOMICRES suffered from funding difficulties due to international attention shifting from post-conflict assistance. Interview with Gary Littlejohn, Harrogate, March 2, 2017.

29. AllAfrica, "Mozambique: Dhlakama Refuses to Disband His Guard," October 6, 2005, https://allafrica.com/stories/200510060517.html.

30. Author witnessed them line up as guard of honor after his meeting with Dhlakama, Nampula, September 23, 2010.

31. Author interviews with FRELIMO officials, Maputo, September 22, 2010.

32. There was an agreement to end hostilities, signed by President Guebuza and Afonso Dhlakama on September 5, 2014, but hostilities resumed in early 2015. For the text of this accord see, https://peacemaker.un.org/ sites/peacemaker.un.org/files/MZ-143508-MozambiqueCeasefire_l.pdf.

33. For a detailed account of this process, see Alex Vines, "Prospects for a Sustainable Elite Bargain in Mozambique: Third Time Lucky?" Chatham House Africa Programme Research Paper, August 5, 2019, https://www.chathamhouse.org/publication/prospects-sustai nable-elite-bargain-mozambique-third-time-lucky.

34. Alex Vines, "Third Time Lucky for Peace in Mozambique?," Mail \& Guardian, August 7, 2019, https://mg.co.za/article/2019-08-07-thirdtime-lucky-for-peace-in-mozambique.

35. Weimer and Carrilho, Political Economy of Decentralisation in Mozambique, 49-52.

36. Roberta Holanda Maschietto, Beyond Peacebuilding: The Challenges of Empowerment Promotion in Mozambique (London: Palgrave Macmillan, 2016), 268.

37. Maschietto, Beyond Peacebuilding, 216.

38. Orre and Rønning, Mozambique: A Political Economy Analysis, 18; and Lars Buur, "The Development of Natural Resource Linkages in Mozambique: The Ruling Elite Capture of New Economic Opportunities," DIIS Working Paper 3 (2014), https://rucforsk.ruc.dk/ws/files/55471747/ Buur_Ruling_Elite_Capture_DIIS_WP_2014_03.pdf. 
39. Nicolas Cook, "Mozambique: Politics, Economy, and U.S. Relations," Congressional Research Service, R45817, September 12, 2019, https:// fas.org/sgp/crs/row/R45817.pdf.

40. Carlos Castel-Branco and Fernanda Massarongo, et al., "Mozambique's Secret Debt: The Impact on the Structure of the Debt and the Economic Consequences," IDeIAS no. 86 (Maputo: IESE, 2016).

41. Adriano Nuvunga and Aslak Orre, "The 'Secret Loans Affair' and Political Corruption in Mozambique," in Political Corruption in Africa: Extraction and Power Preservation, Inge Amundsen (ed.) (Cheltenham, UK and Northampton, MA, USA: Edward Elgar, 2019), 116-135.

42. Nuvunga and Orre, The 'Secret Loans Affair' and Political Corruption in Mozambique, 116-135.

43. Alex Vines, "Remembering a Warlord Democrat," Mail \& Guardian, May 9, 2018, https://mg.co.za/article/2018-05-09-00-remembering-awarlord-democrat.

Open Access This chapter is licensed under the terms of the Creative Commons Attribution 4.0 International License (http://creativecommons.org/licenses/ by $/ 4.0 /)$, which permits use, sharing, adaptation, distribution and reproduction in any medium or format, as long as you give appropriate credit to the original author(s) and the source, provide a link to the Creative Commons license and indicate if changes were made.

The images or other third party material in this chapter are included in the chapter's Creative Commons license, unless indicated otherwise in a credit line to the material. If material is not included in the chapter's Creative Commons license and your intended use is not permitted by statutory regulation or exceeds the permitted use, you will need to obtain permission directly from the copyright holder.

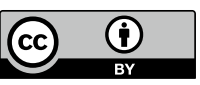

